\title{
Mediation and Agreement of Forestry Cooperation as a Conflict Settlement of Bumi Mekar Hijau LLC Production Forest Area With Community of Riding Village (Case study of Riding village, Ogan Komering Ilir Regency, South Sumatra Indonesia)
}

\author{
Miran Suhardi ${ }^{1 *}$, Zulfikri Suleman $^{2}$, Azwardi $^{2}$ \\ ${ }^{l}$ Master Student at the Environmental Management, Sriwijaya University, South Sumatra, Indonesia. \\ ${ }^{2}$ Lecturer at the Environmental Management, Sriwijaya University, South Sumatra, Indonesia. \\ *Corresponding author: miran.suhardi@gmail.com
}

Article history

\begin{tabular}{llll}
\hline Received & Received from reviced & Accepted & Available online \\
26 January 2019 & 19 February 2019 & 30 March 2019 & 30 March 2019 \\
\hline
\end{tabular}

\begin{abstract}
Conflicts in forest areas usually occur due to unclear rights or laws relating to the tenure system. This can happen between individuals, communities, government agencies or private sector. This study aims to determine conflict dynamics and mediation as a process to resolve the conflict of production forest area. This study is a qualitative research with descriptive data presentation. The Riding Village occupied around 10,000 hectares land because they felt that the company and the government had never asked their permission to make the land an industrial planted forest. The community has evidences that the land belongs to their ancestors, namely "sonor" (planting rice by burning land first) and trenches for timber by their ancestors in the region. In July 2013, the people of Riding Village and Bumi Mekar Hijau LLC agreed to resolve land conflicts through an open, concrete and successful dialogue process. Both parties appointed Wahana Bumi Hijau (WBH) and Imparsial Mediator Networking (IMN) as mediators who assisted the negotiation process. On March 16, 2017 process has taken place, both parties agreed a settlement in Riding village with Bumi Mekar Hijau LLC for 10,000 hectares area.

Keywords: Mediation, conflict resolution, production forest.
\end{abstract}

Abtrak (Indonesian): Konflik dalam kawasan hutan biasanya terjadi akibat tidak jelasnya hak-hak atau hukum yang berhubungan dengan sistem tenurial. Hal ini dapat terjadi antara perorangan, masyarakat, badan/ instansi pemerintah atau sektor swasta. Penelitian ini bertujuan untuk mengetahui dinamika konflik, dan mediasi sebagai proses penyelesaian konflik kawasan hutan produksi. Penelitian ini menggunakan metode penelitian kualitatif dengan penyajian data secara deskriptif. Masyarakat Desa Riding menduduki lahan seluas \pm 10.000 hektar karena mereka merasa pihak perusahaan maupun pemerintah tidak pernah meminta izin kepada mereka untuk menjadikan lahan sebagai hutan tanaman industri (HTI). Masyarakat memiliki bukti kalau lahan tersebut adalah milik nenek moyang mereka yaitu tempat menanam padi dengan cara membakar lahan dan parit tempat mencari kayu oleh nenek moyang mereka di wilayah tersebut. Pada bulan juli tahun 2013 bahwa masyarakat Desa Riding dan PT Bumi Mekar Hijau bersepakat menyelesaikan konflik lahan melalui proses dialog yang terbuka, konkrit dan berhasil, kedua belah pihak menunjuk Wahana Bumi Hijau (WBH) dan Imparsial Mediator Networking (IMN) selaku mediator yang membantu proses perundingan.. Pada 16 maret 2017 kedua belah pihak menyepakati penyelesaian konflik Desa Riding dengan PT Bumi Mekar Hijau dengan luasan areal 10.000 hektar.

Kata kunci : Mediasi, penyelesaian konflik, hutan produksi.

\section{Introduction}

Conflicts in forest areas usually occur due to unclear rights or laws relating to the tenure system. This can happen between individuals, communities, government agencies or a private sector. The boundaries of forest areas that have not been agreed upon by the community and the government also trigger conflict. The reality in the field shows that the land in the forest area has been utilized by the community or the surrounding population, both migrants and local residents, but the existence of these communities has not been accommodated especially in forestry development planning ${ }^{[1]}$.
The development of industrial planted forest and backgrounds. The development of industrial planted forest and motivated more by the emergence of a large number of unproductive production forests and incentives that attract the private sector. Meanwhile, the development of plantations, especially oil palm is more stimulated by the high demand for export markets. Government policies concerning forest conversion and land use as well as various investment ease packages encourage growth in the sector's development ${ }^{[2]}$.

Natural resource conflicts, including land conflicts, are increasingly prevalent in the last decade. The conflict occurred with the coverage of the region, 
the parties involved and the wider impact. This condition is caused by Forestry as one of the sectors that are authorized by law to control a land area of 136.94 million hectares $(65 \%$ of the total area of Indonesia), of course, does not escape the problem of land conflicts. Facts on the ground indicate a large number of forest areas occupied by the community to be used as residential, infrastructure, village, agricultural and plantation areas. This condition is indicated by the existence of cases of land conflicts in the forestry sector which reached 72 cases with an area of more than 1.2 million hectares ${ }^{[3]}$.

In the context of Production Forests and plantation forest product utilization permits in Bumi Mekar Hijau LLC Industrial Planted Forest in the Riding Village of Ogan Komering Ilir District which is the location of this study, the prominent problem is the conflict between private parties (in this case by Bumi Mekar Hijau LLC) with the community of Riding Village. The point of the problem is on land tenure claims, on the basis of territorial territoriality, by the private sector and the existence of communities that carry out activities within the area. This Production Forest area has been entered into and cultivated by the community since 1992 after the Forest Concession Decree (FCD) of Inwihco LLC, Daya Penca LLC and Seribunian LLC were revoked in 1991 and in 19971998 the production forest area caught fire. And encroached as a place to grow rice, find fish and look for wood. The population in this area is mostly indigenous people of Riding Villafe, Pangkalan Lampam Sub-District, Ogan Komering Ilir Regency, South Sumatra.

Conflict occurs between Bumi Mekar Hijau LLC with the community of Riding Village openly starting around 2005 and this was met with resistance from Wahana Bumi Hijau (WBH) South Sumatra NonGovernmental Organization (NGO). The institute is advocating because of the company's actions and the arbitrary government opening up community land and culminating when the company will open land in 2006 and one employee down to the Village by Riding communities to sign an agreement that an area of 10,000 hectares community management rights and intended by the community.

From 2005 to 2013, conflicts resolution process has not been resolved yet. In July 2013 a meeting was held between the company, the Riding Village Community, the government, the mediator to agree to make a joint statement to resolve the Company's land conflicts through a mediation process. In March 2017 the resolution of the conflict ended with the existence of a peace agreement with both parties between Bumi Mekar Hijau LLC and the Riding community to reconcile in the form of Memorandum of
Understanding (MoU signed by the company, Head of Riding Village, Community leaders of Riding Village, mediator, Ministry of Environment and Forestry, TRIPIKA (Head of Sub-District, military commander and police). The existence of the forest in the production area is basically part of the territorial process carried out by the state, which then deals with the existence of the community in the region. The existence of the forest in the production area is basically part of the territorial process carried out by the state, which then deals with the existence of the community in the region. The existence of the community, as mentioned above, is very much related to the economic aspects. the production of Bumi Mekar Hijau LLC is, as an economic asset. In the context of environmental ethics, this is identical to the anthropocentric point of view, which views nature as an area that can be exploited and can be used for human needs ${ }^{[4]}$.

\section{Methods}

This research was carried out at the location of the business permit for the utilization of plantation forest in Industrial Planted Forest (IUPHHK-HTI) Bumi Mekar Hijau LLC is administratively located in the Riding Village of Pangkalan Lampam Sub-District, Ogan Komering Ilir Regency, South Sumatra Province. The choice of location was taken into consideration that the Production Forest area became a conflict area from 2005 to 2017.

The time of the study was carried out in March to May 2018. This research was carried out at the location of residents who live near to the production forest area that holds the license of Bumi Mekar Hijau LLC in Riding Village Hamlets I and II. This location is based on its involvement in conflicts and conflict resolution that have occurred. This study uses qualitative research methods with descriptive data presentation. Qualitative methods are defined as research procedures that produce description data in the form of written or oral words from people and observed behavior amounted to 18 persons consisted of the Government, NGOs, community and company.

The aim is to explain the phenomena of collecting data in depth. The population and sampling in qualitative research are very limited. With population limitations and sampling, collected data must be indepth and can explain the phenomenon under study. The issue of the depth of data quality is more highlighted in this study. Data analysis was carried out by means of an inherent analysis of each aspect of the forest concession conflict case found. The analysis is also based on existing conflict themes in accordance with the results of the interpretation of the cases found (object of conflict map attached). 


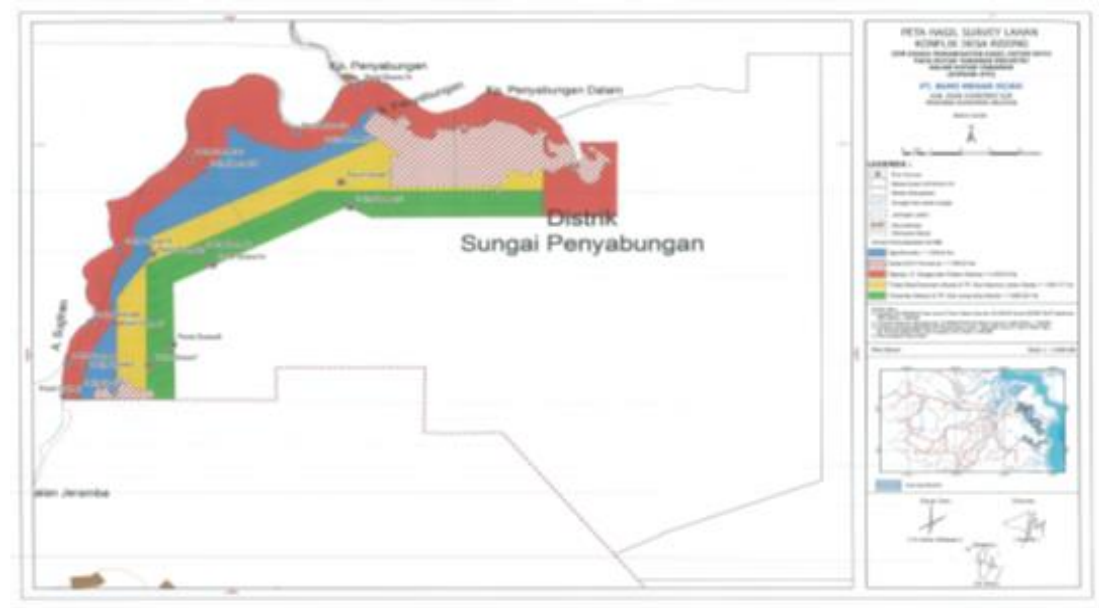

Figure.1 : Map of Industrial Estate Production Forest Area Location of Bumi Mekar Hijau LLC Conflicting with Riding Village Community, Pangkalan Lampam District

\section{Results and Discussion}

\subsection{History of Production Forest Conflict between Bumi Mekar Hijau LLC and the Riding Village Community}

In the early 1990s, the era of forest concessions (FC) had not yet opened up in the area of Riding Village. The timber extraction activities did not significantly affect the lives of the people of Riding Village in their hamlets. Forest concession companies do not interfere with villages, fields and plantations of the Riding Village community. The forest concession company actually involved a portion of the Riding Village community in logging activities. This was told by the community leaders of Riding Village. The relationship between the forest concession company and the community is quite harmonious. They need each other. The company as a newcomer in the neighborhood needs the people of Riding Village who already recognize the forest in their area. While the community will get additional income by helping companies cut down trees and sell the results to the company.

This condition experienced a change from 1997 to 1998 when a large fire happened in the area of forest concession so that the villagers could no longer look for timber and the only source of life was fishing. In 2004 forest concession company were granted business licenses for utilization of plantations in Industrial Planted Forests Bumi Mekar Hijau LLC for the Opening of Plantation Forests. The acacia wood industry, which is one of the private sector enterprises (BUMS) in the forestry sector, began to enter the Riding Village area in 2004. The conflict was opened when Bumi Mekar Hijau LLC began clearing forests in the communities of Riding Village, Hamlet I and II in 2004. Bumi Mekar Hijau LLC obtained a business license for utilization of plantation forest products in industrial planted forests based on the Minister of Forestry Decree Number SK. 338/Menhut-II/ 2004,
September 7, 2004, with an area of 127,870 $\mathrm{Ha}$ and the working area of Bumi Mekar Hijau LLC increased to $250,370 \mathrm{Ha}$, which is based on the Decree of the Minister of Forestry Number SK. 417/Menhut-II/2004, dated October 19, 2004 and gave management rights to the production forest land to Bumi Mekar Hijau LLC. The permit can be extended later if the conditions are met in accordance with the applicable laws and regulations. Production forest land provided by the government to Bumi Mekar Hijau LLC in fact is a thicket of land that is not a land of occupants and without ownership. The land is a former forest concession of Inwihco LLC, Daya Penca LLC and Sribunian LCC, The permit was terminated / revoked in 1991 Tens of years ago the community opened a trench to remove wood and planting rice by burning land first in the area. They named the area "planting rice by burning land first and wood trenches" ${ }^{[5]}$.

\subsection{The root cause of conflict}

Based on the analysis result of the history of the conflict above, we can identify the root causes of the conflict. The root of conflict is fundamental differences that cause conflict to occur. Usually conflict has multiple interconnected causes. View that human intervention on the environment will affect the environment as a whole is the initial theory which is the basis of the analysis of the conflicts that occurred in Riding Village. Government intervention by giving management rights to the private sector to develop acacia production forests on the forest land of the Riding Village not only causes the loss of tens of thousands of Indonesian tropical forests but also the loss of the rights of Riding communities to ancestral lands which they have managed for hundreds of years ago.

The choice of policy carried out by the government through business licenses for utilization of plantation forest products in industrial planted forests 
is inseparable from the development paradigm used. The development paradigm that promotes economic growth as the main way to realize community welfare, and uses a sectoral approach in its application, has caused many conflicts over natural resource management. This happens because the land given to the private sector through business licenses for the utilization of plantations in industrial planted forests is not land without occupants and is free of value. The community has been managing the area for hundreds of years before Bumi Mekar Hijau LLC entered.

\subsection{Types of Conflict}

From the analysis of the history and causes of the conflict above, it can be concluded that the type of conflict that occurred between Riding communities and the Industrial Planted Forest in Ogan Komering Ilir District was a Type of Open Conflict. Latent conflict began to occur when the government began giving permission to the private sector to open production forests for industrial use and the development of acacia plants by Bumi Mekar Hijau LLC. The forests which are the community management areas of the Riding Village are open massively with an inequitable process.

The act of occupying land in the area of business license for utilization of plantations in industrial planted forests which used to be the land of ancestors seeking wood and sonor (planting rice), was the initial cause of open conflict between the two parties. Claims made by the community are a manifestation of the people's struggle for land rights that have been taken over by plantation companies with government permission. The act of controlling land in a production forest area by the company is a form of use of legal instrumentation by companies in order to maintain the sustainability of their industrial planted forests. The people of Riding Village are considered criminals who interfere with industrial planted forest businesses. The perspective and choice of resolving the conflict has led to many open conflicts that leave losses that are not small to both parties.

\subsection{Analysis of Conflict Dynamics}

Conflict will change at any time through different stages of activity, intensity, tension and violence. Through the analysis of conflict phasing, a graph will be found which shows the increase and decrease in the intensity of the conflict (escalation and de-escalation of conflict) which will be described on a certain time scale, so that it is known to the extent of the conflict. Analysis of conflict phasing will facilitate the preparation of conflict resolution strategies ${ }^{[6]}$.

Conflict began when construction of acacia plantations with the mechanism of obtaining business licenses for utilization of plantations in industrial planted forests in the Riding Village area. The opening of industrial planted forests has already made land for cultivation and community gardens in Riding Village, while population growth has made the need for cultivated land and land even greater. These two contradictory things cause scarcity of natural resources, namely land. Until this stage the condition can be considered as a pre-conflict stage. The community has begun to feel discomfort. Their lives that are very dependent on forests and fields are becoming increasingly difficult. They lose their livelihood. They feel disadvantaged by the existence of acacia industrial planted forests. But they have not been able to speak out because in conditions they prioritize security and stability. Tensions and community dissatisfaction with the conditions that occur in the area of their lives at that time can only be felt by themselves.

In 2005 the first violent conflict occurred. Conflict begins to enter the stage of confrontation and crisis, where conflict becomes open. Both parties, both Riding communities and companies mobilized their respective abilities and resources to show that they existed and tried to eliminate the opposition of their enemies. The company deployed its security division and was assisted by members of the Indonesian National Police who were leased by the company to mediate with the people of Riding Village but there were no armed clashes. Indonesian National Police with firearms maintain the security of Industrial Planted Forest areas and employees. But the community remained on the land of Riding Village.

After the hostage taking of company employees there was still small-scale intimidation of employees carried out by the community which occurred in 2005 . 2005-2006 violent incidents did not occur again. The company held a meeting with the community of Riding Village, located in the location of the one-village Riding Village. News of the company hostage taking place immediately appeared in various mass media. Several NGOs such as Wahana Bumi Hijau, United Riding Organization, accompanied the residents to hold a demonstration at the Office of the Governor of South Sumatra.

From 2007 until 2012 open conflicts seemed to subside and in July 2013 began to enter the postconflict phase which was marked by the choice of mediation and negotiation carried out by the parties in conflict. The NGO Wahana Bumi Hijau (WBH) and Imparsial Mediator Networking (IMN) assistance by making a joint agreement to resolve conflicts has produced significant results. On October 2, 2013 the first mediation of the Riding community conveyed their demands:

1. Development of a 5000 ha rubber plantation (status of permanent production forest area).

2. The remaining claim area of 5000 ha for Industrial Planted Forest development with a profit sharing system between the company and the community 
3. Development compensation that has been tried so far both in the past and for development activities is realized in aid programs

4. There are priorities for the procurement of labor and sub-contracts of employment.

Based on the expectations of the Riding Village community, the company needs to conduct a land suitability/feasibility test first in order to provide benefits to the community, and then an official response will be given at the next meeting, which was agreed to be held on October 22, 2013. In the minutes it was stated that community representatives guaranteed that no other party would make claims after this agreement.

Second mediation result. The Mediator team, company and community of Riding Village, OKI District Forest Service, The Forest Trust, Asia Pulp and Paper conducted participatory mapping to find out the boundaries and extent of the conflict area between Riding communities and Bumi Mekar Hijau LLC. On June 20, 2014 the third mediation at the Grand Duta Hotel Palembang, failed to discuss options for resolving conflicts because the number of representatives of the community was not quorum. However, the meeting between Bumi Mekar Hijau LLC and the Riding Community continued. The results of the meeting were "The representatives of the Riding Village community conveyed the changes and additions to the negotiating team members, arguing that there were members who had died and some had resigned. The change is also intended to increase community representation. Responding to the changes in community representatives, Bumi Mekar Hijau LLC requested changes to the community team must be accompanied by a letter of resignation from the old team as well as a statement that they would accept whatever results were taken by the new team and there would be no demands later."

The third mediation was continued on 25 to 26 November 2014 which was attended by both parties, with achievements in the form of:

1. Both parties agreed to delineate the spatial layout of an object covering 10,000 hectares divided into two zones.

2. In zone 1 an area of 4,390 ha will not be managed as a staple plant by Bumi Mekar Hijau LLC which consists of:

a. Road covering an area of 1,000.8 hectares

b. Residential area of 333.6 hectares

c. The buffalo forage area is $1,863.4$ hectares

d. The river border protected area is $1,192.2$ hectares

1) In zone 2 an area of 5,610 hectares is managed together with Bumi Mekar Hijau LLC and the community which consists of:

a. The partnership program for the acacia type and mix up an area of 2000 hectares b. The partnership on food crops covering 3000 hectares is divided into 2 zones, namely the food crop zone with a pattern of community empowerment covering 1000 ha and a zone that can be managed by a third party covering 2000 ha.

c. In the zone of food crops with a pattern of community empowerment carried out with the following provisions:

- land preparation, drainage excavation, nursery from the company;

- planting, maintenance, protection of plants, crops and produce by the community;

- the creation of village cooperatives, monitoring and evaluation carried out by companies and communities.

- In the food crop zone with third parties covering an area of 2000 ha carried out with mutual agreement between the company and the community.

On July 19, 2016 mediation was conducted between PT Bumi Mekar Hijau LLC and the community of Riding Village, Pangkalan Lampam sub-district, OKI district, the southern Sumatran province was facilitated by the Director of handling tenure conflicts and customary forests of the Ministry of Environment and Forestry. The meeting was chaired by the Director of Indigenous Forestry and Tenurial Conflict Management and was attended by the Head of the Ogan Komering Ilir District Forestry Service, representatives of the South Sumatra Provincial Forestry Service Office, Head of the Conflict Management Subdistrict and staff, the Imparsial Mediator Networking Director, Bumi Mekar Hijau LLC representative, Sinarmas representative Forestry, as well as representatives of the Riding Village community. In handling the conflict, the Directorate for handling tenurial and customary forest conflicts expects that the South Sumatra Provincial Forestry Service can be involved more deeply because the local government is more aware of the situation and conditions in the site area. The government is expected to be able to coordinate the parties in handling conflicts other than acting as facilitators. In this case the central government acts as a negotiating node that has a neutral position in the course of mediating the handling of conflicts. In terms of implementing the agreement, there is no need to wait for the agreement of the entire village community because an agreement can be implemented.

Therefore the company can start with a community that has agreed (800 families in the village of Riding) in the form of mutual agreement between the community and the company so that it can create a better situation for the parties. For this reason, some things that need to be done include: 
1. make a demonstration plot as a pilot material for the community

2. compile a conflict map to determine which party has agreed to an agreement with the party that has not been able to approve it

3. make a timeline for work plans for the parties

4. determine the person responsible for each activity and the reporting node and coordination between the parties and the central government and the regional government

5. Involving community leaders

6. Compile measurable report material to be reported in an audience to the Regent of Ogan Komering Ilir by using the appropriate language and delivery strategies.

On March 16, 2017, Memoriam off Understanding (MoU) of peace conflict in Riding Village with Bumi Mekar Hijau LLC was held, located at the Forestry Service of South Sumatra Province which was attended by the Village Government and the community of Riding Village, Bumi Mekar Hijau LLC, Tripika District. Pangkalan Lampam, Mediator, APP, District Forestry Service OKI, South Sumatra Province Forestry Service, Director of handling tenurial and customary forest conflicts and Director of Sustainable Production Forest Management.

From the above conditions, it can be seen that a force is needed which can force all parties to comply with the results of negotiations. The capacity and ability of the mediator is a crucial key. In this case the NGO does not have the capacity and ability to ensure the results of mediation can be carried out by all parties in conflict. The regional government as an institution that has the authority to protect all communities that should have strong political will to ensure that the mediation results can be carried out.

\subsection{Conflict Resolution Strategy}

Based on the results of mapping analysis and conflict dynamics, a conflict resolution strategy was conducted in two steps, namely Conflict Handling Analysis and Need Analysis. Considering that the conflict between Riding communities and industrial planted forest companies has been going on for a long time with various escalations and de-escalation of conflicts, an analysis of the handling of conflicts that have been carried out is needed so that any efforts will be identified by the parties to resolve conflict and why the conflict resolution effort failed to achieve its goal of conflict resolution. The results of the analysis of various conflict resolution efforts will be noted in the preparation of a more comprehensive conflict resolution strategy through needs analysis.

Needs analysis is carried out to identify gaps between current conditions and their intended conditions, so that they can produce fair conflict resolution strategies. The results of the analysis are expected to be used to develop alternative problem solving that is in accordance with the needs of the parties. The steps of the needs analysis are carried out as follows: 1. Identify the actual conditions; 2 . Identification of the needs of the parties; 3. Preparation of conflict resolution strategies based on the effectiveness of time and costs, the government's political will, opportunities ${ }^{[7]}$.

\subsection{Settlement of Conflict Handling that Has Been Done}

The conflict resolution strategy with the mediation system is a manifestation of the Alternative Dispute Resolution (ADR) method that has been carried out by the parties. In this conflict, the government joined local and national NGOs to position themselves as mediators in negotiations. The mediation process reached an agreement because the two parties that mediated were the company and the community, from the mediation process by reason of having the same thoughts to resolve the conflict and provide a useful solution for both people.

The company's commitment to choose the Alternative Dispute Resolution (ADR) mechanism and the Forestry Cooperation Agreement (NKK) for conflict resolution with the people of Riding Village not only tend to be on the economic side, but thinks to maintain a long-term relationship with the community of industrial planted forest companies according to the commitment to recognize and respect the rights of local communities in and around the company's concessions. If viewed from an economic standpoint, the decision certainly is very detrimental to the company. The company's choice of the Alternative Dispute Resolution (ADR) mechanism and the Forestry Cooperation Agreement Note (NKK) is not an awareness of obtaining justice for all parties and the Riding Community, but more about the forestry regulations, long-term economic considerations of the community and recognizing and respecting the rights of the community local.

The economic, social and cultural interests of Riding community, the economic interests of the company and the interests of the government must meet and merge into mutually agreed conflict resolution ${ }^{[8] .}$ The socio-cultural interests of the people of Riding Village are the recognition of the government, companies and all parties to their rights to the land of management right so they can live in peace and dignity just like other communities in Indonesia. The economic interests of the community are a decent livelihood for all the people of Riding Village. Fixed livelihood and avoid the monopoly of any party. The economic interests of the company certainly benefit as much as possible and avoid the disruption of industrial planted forest business in any form. The government's interest in this matter is to get foreign exchange from the export of products from acacia plants and improve people's welfare and provide employment. The 10,000 
hectare forestry cooperation agreement with the Riding community is a form of problem solving that is a "winwin solution" both from the side of the government, companies and the community. Recognition and appreciation of the rights of the people of Riding Village will be realized in a joint action by the parties, namely with the agreement on forestry cooperation in the 10,000 hectare area, the existence of the community of Riding Village has been recognized as part of the community that has the same human rights as the Indonesian people.

Conflict resolution in this study is a strategy that uses the Alternative Dispute Resolution (ADR) mechanism and the Forestry Cooperation Agreement (NKK) to resolve conflicts with the existence of corporate acacia plant partnerships and agroforestry from the mediation process. Companies and communities can continue to be committed to resolving conflicts.

\section{Conclusion}

The conclusions that can be derived from this study are:

1. The community of Riding Village has a very large dependence on natural resources, especially forests. When forests which are "living areas".

2. Conflict resolution in this study uses an approach through dialogue involving a special group of village government, influential community leaders. The similarity of the viewpoint on the importance of reaffirming the rights of village communities is the starting point used as a benchmark in determining conflict resolution options.

3. After obtaining permits for natural resource management, Industrial planted forest companies need to conduct socialization, tenure studies and Free Prior Informed Consent before conducting operations. This is done to determine the rights of community land management that have been carried out so it can minimize land conflicts.

\section{References}

[1] S. Sylviani and I. Hakim, " Analysis of Tenurials in the Development of Forest Management Units (KPH): Case Study of KPH Gedong Wani, Lampung Province," Journal of Forestry Social and Economic Research, vol. 11, no. 4, , 2014.

[2] H. Kartodihardjo and A. Supriono, Impact of sectoral development on natural forest conversion and degradation: cases of Industrial Planted Forest and plantation development in Indonesia: Center for International Forestry Research, 2000. Pp. 412.

[3] M. K. Harun and H. Dwiprabowo, " Model of land conflict resolution in the unit of production forest in the Banjar model," Journal of Forestry Social and Economic Research. vol. 11, no. 4, , 2014.
[4] A. S. Keraf, "Environmental Ethics". Penerbit Buku Kompas, pp 47, 2010.

[5] PT Bumi Bumi Mekar." Bumi Mekar Hijau (RKUBMH) General Work Plan, Ogan Komering Ilir Regency, South Sumatra Province”.2015, pp. $1-19$.

[6] Fisher, S, Abdi, D. D.I, Ludin, J, Smith, R, Williams, S, Williams, S, "Managing Conflict" Skills and Strategies for Acting. Indonesian edition. British Council Indonesia. S. Widjoyo, Vol. 27, pp 3 IqYO, 2001

[7] Nilakrisna, D, Land Social Conflict Between Large-Scale Oil Palm Plantation Companies and Customary Law Communities (Case Study of Sungai Beruang Hamlet, Batanghari District, Jambi Province). Dissertation. Sriwijaya University. Palembang, 2016, Pp 52.

[8] Tahyudi, D, 2014. Forest Management Conflict Management Model of Bentayan Wildlife Reserve in the Province of South Sumatra Province. Dissertation. Sriwijaya University. Palembang, 2014, Pp 226-231. 